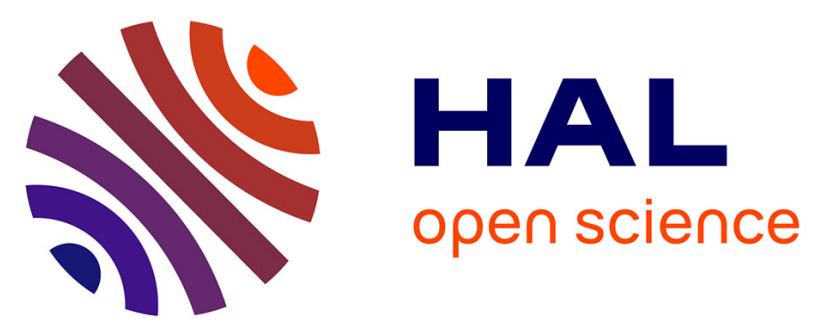

\title{
Phasic hemodynamics and reverse blood flows in the aortic isthmus and pulmonary arteries of preterm lambs with pulmonary vascular dysfunction
}

Pierre-Henri Rolland, Pascal de Lagausie, Euletheris Stathopoulos, Olivier Leprètre, Gilles G. Viudes, Guillaume Gorincour, Géraldine Héry, Catherine de Magnée, Olivier Paut, Jean-Michel Guys

\section{To cite this version:}

Pierre-Henri Rolland, Pascal de Lagausie, Euletheris Stathopoulos, Olivier Leprètre, Gilles G. Viudes, et al.. Phasic hemodynamics and reverse blood flows in the aortic isthmus and pulmonary arteries of preterm lambs with pulmonary vascular dysfunction. AJP - Heart and Circulatory Physiology, 2008, 295 (6), pp.H2231-H2241. 10.1152/ajpheart.00410.2008 . hal-02668212

\section{HAL Id: hal-02668212 \\ https://hal.inrae.fr/hal-02668212}

Submitted on 31 May 2020

HAL is a multi-disciplinary open access archive for the deposit and dissemination of scientific research documents, whether they are published or not. The documents may come from teaching and research institutions in France or abroad, or from public or private research centers.
L'archive ouverte pluridisciplinaire HAL, est destinée au dépôt et à la diffusion de documents scientifiques de niveau recherche, publiés ou non, émanant des établissements d'enseignement et de recherche français ou étrangers, des laboratoires publics ou privés. 


\section{Pierre-Henri Rolland, Pascal de Lagausie, Euletheris Stathopoulos, Olivier Leprètre, Gilles Viudes, Guillaume Gorincour, Géraldine Hery, Catherine de}

Magnée, Olivier Paut and Jean-Michel Guys

Am J Physiol Heart Circ Physiol 295:2231-2241, 2008. First published Sep 26, 2008;

doi:10.1152/ajpheart.00410.2008

You might find this additional information useful...

This article cites 62 articles, 37 of which you can access free at:

http://ajpheart.physiology.org/cgi/content/full/295/6/H2231\#BIBL

Updated information and services including high-resolution figures, can be found at:

http://ajpheart.physiology.org/cgi/content/full/295/6/H2231

Additional material and information about AJP - Heart and Circulatory Physiology can be found at:

http://www.the-aps.org/publications/ajpheart

This information is current as of September 7, 2010 .

AJP - Heart and Circulatory Physiology publishes original investigations on the physiology of the heart, blood vessels, and

lymphatics, including experimental and theoretical studies of cardiovascular function at all levels of organization ranging from the intact animal to the cellular, subcellular, and molecular levels. It is published 12 times a year (monthly) by the American

Physiological Society, 9650 Rockville Pike, Bethesda MD 20814-3991. Copyright @ 2008 by the American Physiological Society.

ISSN: 0363-6135, ESSN: 1522-1539. Visit our website at http://www.the-aps.org/. 


\title{
TRANSLATIONAL PHYSIOLOGY
}

\section{Phasic hemodynamics and reverse blood flows in the aortic isthmus and pulmonary arteries of preterm lambs with pulmonary vascular dysfunction}

\author{
Pierre-Henri Rolland, ${ }^{1}$ Pascal de Lagausie, ${ }^{2}$ Euletheris Stathopoulos, ${ }^{2}$ Olivier Leprètre, ${ }^{3}$ Gilles Viudes, ${ }^{5}$ \\ Guillaume Gorincour, ${ }^{1,4}$ Géraldine Hery, ${ }^{2}$ Catherine de Magnée, ${ }^{2}$ Olivier Paut, ${ }^{3}$ and Jean-Michel Guys ${ }^{2}$ \\ ${ }^{1}$ Physiopathology and Vascular Therapeutics, School of Medicine, University of the Mediterranean Sea, Marseilles; \\ Departments of ${ }^{2}$ Pediatric Surgery Department, ${ }^{3}$ Pediatric Reanimation, and ${ }^{4}$ Pediatric Radiology, LaTimone-Hospital, \\ Marseilles; and ${ }^{5}$ National Institute for Agronomic Research, Montpellier, France
}

Submitted 18 April 2008; accepted in final form 22 September 2008

\begin{abstract}
Rolland PH, de Lagausie P, Stathopoulos E, Leprètre O, Viudes G, Gorincour G, Hery G, de Magnée C, Paut O, Guys JM. Phasic hemodynamics and reverse blood flows in the aortic isthmus and pulmonary arteries of preterm lambs with pulmonary vascular dysfunction. Am J Physiol Heart Circ Physiol 295: H2231-H2241, 2008. First published September 26, 2008; doi:10.1152/ajpheart.00410.2008.Time-domain representations of the fetal aortopulmonary circulation were carried out in lamb fetuses to study hemodynamic consequences of congenital diaphragmatic hernia $(\mathrm{CDH})$ and the effects of endothelin-receptor antagonist tezosentan $(3 \mathrm{mg} / 45 \mathrm{~min})$. From the isthmic aortic and left pulmonary artery (PA) flows (Q) and isthmic aortic, $\mathrm{PA}$, and left auricle pressures (P) on day 135 in 10 controls and 7 $\mathrm{CDH}$ fetuses (28 ewes), discrete-triggered $\mathrm{P}$ and $\mathrm{Q}$ waveforms were modelized as $\mathrm{P}_{t}$ and $\mathrm{Q}_{t}$ functions to obtain basic hemodynamic profiles, pulsatile waves $\left[\mathrm{P}, \mathrm{Q}\right.$, and entry impedance $\left.\left(Z_{\mathrm{e}}\right)\right]$, and $\mathrm{P}$ and $\mathrm{Q}$ hysteresis loops. In the controls, blood propelling energy was accounted for by biventricular ejection flow waves (kinetic energy) with low $Z_{\mathrm{e}}$ and by flow-driven pressure waves (potential energy) with low $Z_{\mathrm{e}}$. Weak fetal pulmonary perfusion was ensured by reflux (reverse flows) from PA branches to the ductus anteriosus and aortic isthmus as reverse flows. Endothelin-receptor antagonist blockade using tezosentan slightly increased the forward flow but largely increased diastolic backward flow with a diminished left auricle preand postloading. In CHD fetuses, the static component overrode phasic flows that were detrimental to reverse flows and the direction of the diastolic isthmic flow changed to forward during the diastole period. Decreased cardiac output, flattened pressure waves, and increased forward $Z_{\mathrm{e}}$ promoted backward flow to the detriment of forward flow (especially during diastole). Additionally, the intrapulmonary arteriovenous shunting was ineffective. The slowing of cardiac output, the dampening of energetic pressure waves and pulsatility, and the heightening of phasic impedances contributed to the lowering of aortopulmonary blood flows. We speculate that reverse pulmonary flow is a physiological requirement to protect the fetal pulmonary circulation from the prominent right ventricular stream and to enhance blood flow to the fetal heart and brain.
\end{abstract}

fetal pulmonary circulation; congenital diaphragmatic hernia; pulmonary reverse flows; pulsatile impedance; endothelin receptor inhibitor

THE PULMONARY CIRCULATION in the preterm fetal lamb (see Fig. 1) is hemodynamically unique because the distribution of the combined ventricular output is $40 \%$ to the placenta versus only about $7 \%$ to the lungs $(1,22,33,51,52)$. Central vascular

Address for reprint requests and other correspondence: P. H. Rolland $\mathrm{P}_{2}$ VTL, School of Medicine, 27 Blvd. Jean-Moulin, 13385 Marseille cedex 5, France (e-mail: pierre-henri.rolland@univmed.fr). shunting leads to a communication of the pulmonary and aortic circulation with driving pressures that would be considered as hypertensive if it persisted after birth $(1,14,47)$. These characteristics are functionally optimal for the fetal lung that does not participate in gas exchange and requires only a small amount of blood for development $(14,23,25,27,47)$. In previous studies we used the preterm fetal lamb model to study lung hypoplasia caused by a congenital diaphragmatic hernia $(11,61)$ and the porcine thoracic and abdominal aorta model to study anatomical bypass- and stenting-induced hemodynamic changes $(38,39,48)$. The purpose of the present study was to investigate two hypotheses that we have formulated based on previous studies. As elaborated below, hypothesis 1 is that phasic pulmonary vascular resistances (PVRs) have been overestimated, and hypothesis 2 is that reverse pulmonary flows contribute to reverse isthmic flows. We also studied the effect of administering an endothelin-receptor antagonist (ERA) tezosentan (TZ) in the left pulmonary artery (LPA).

Hypothesis 1 . The high fetal PVRs that are consistently used to explain the low pulmonary perfusion have been estimated based on the ratio of the mean transpulmonary pressure gradient to the mean transpulmonary flow $(1,4,14,22,28,29,33$, $45,51,52)$. Similarly, the input impedance spectrum of pulsatile fetal pulmonary artery (PA) hemodynamics, estimated in the frequency-domain analysis, has been used to characterize right ventricular (RV) afterload, proximal arterial compliance, distal vascular resistance, wave-transmission properties, and pulse wave interactions causing phenomena such as reverberations and wave amplification $(4,8,28,45,46,63)$. However, frequency domain analysis does not take into account the perfusion of the fetal pulmonary parenchyma by a direct venous admixture from intrapulmonary arteriovenous shunting (iPAVS) $(8,13,21,34,37,56,58,63)$. The iPAVS (see Fig. 2) is dependent on the supernumerary vessel group that branches from the small PAs at a right angle and acts as a parallel vascular network limiting distal pulmonary perfusion. In lamb fetuses, iPAVS normally occurs during late gestation and the early neonatal period and disappears thereafter. Finally, the frequency domain analysis does not take into account reverse flows from the pulmonary circulation to the ductus arteriosus (DA) and aortic isthmus. These shortcomings of frequency

The costs of publication of this article were defrayed in part by the payment of page charges. The article must therefore be hereby marked "advertisement" in accordance with 18 U.S.C. Section 1734 solely to indicate this fact. 
Fig. 1. Typical heart [ventral (left) and dorsal $(r i g h t)]$ from a lamb fetus with congenital diaphragmatic hernia $(\mathrm{CDH})$ and pulmonary vascular dysfunction (PVD) illustrating size differences between great vessels. PA, pulmonary artery; DA, ductus arteriosus; Ao, aorta; LPA, left PA; BCT, bracchiocephalic trunk.
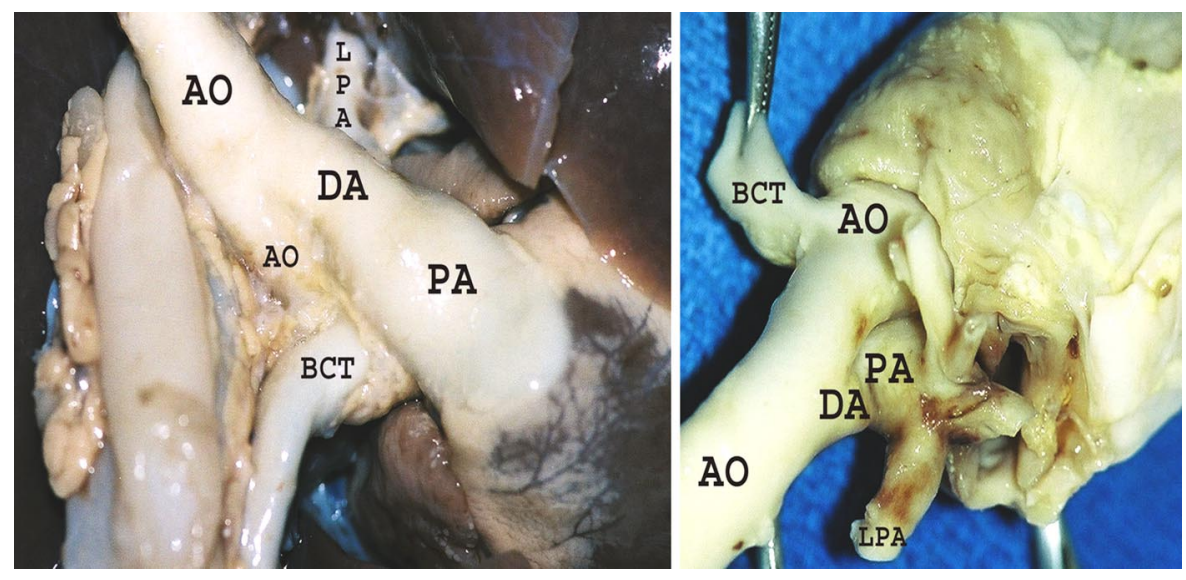

domain analysis led us to consider that PVRs have been consistently overestimated and that this can be demonstrated by reassessing the preterm lamb fetal hemodynamic based on phasic flow-pressure relationships in impedance profiles and hysteresis loops in the time domain during the cardiac cycle with mathematical modeling of discrete, averaged and timesynchronized pressure $(\mathrm{P})$ and LPA flow $(\mathrm{Q})$ signal waves to obtain their respective $\Omega_{\mathrm{P}}(t)$ and $\Omega_{\mathrm{Q}}(t)$ functions and instantaneous entry impedance $\left(Z_{\mathrm{e}}\right)$ as the ratio of $\Omega_{\mathrm{P}}(t)$ and $\Omega_{\mathrm{Q}}(t)$ functions $(5,38,39,48,50)$.

Hypothesis 2. The fetal DA is the main vascular outlet of the prominent fetal RV. It forms the pulmonary arch with the main PA and descending thoracic aorta $(1,16,20,33,51,52)$. Blood from the fetal RV perfuses subdiaphragmatic organs with $10-15 \%$ going to the pulmonary circulation while blood from the left ventricle (LV) perfuses cephalic regions $(16,22,30$, 51). These two arterial flows merge at the junction of the aortic isthmus and DA with the descending aorta. This arrangement implies that output from the RV and LV has opposing effects on flow through the isthmus with LV output causing forward flow and RV output causing backward flow. When reverse flow develops in the aortic isthmus, the preplacental blood with low oxygen saturation coming from the descending aorta can mix with the ascending aortic blood destined to the brain, which can potentially create a risk for cerebral hypoxia $(1,7,19,22$, $33,51,52)$. In ovine fetuses, a stepwise increase in resistance to placental blood flow lowers oxygen delivery to the brain in association with a major reversal of diastolic blood flow through the aortic isthmus $(7,19)$. Oxygen delivery to the brain decreases as the net flow through the aortic isthmus becomes retrograde $(18,19,35,54)$.

Understanding the physiology of the aortic isthmus flow as well as its pathological alterations and potential pharmacological controls is important to ensure optimal fetal growth and maturation until delivery and particularly to prevent nonoptimal neurodevelopment $(18,19,54)$.

An ultrasonographic study of dynamic phasic events during the last months of gestation in normal fetuses has shown that

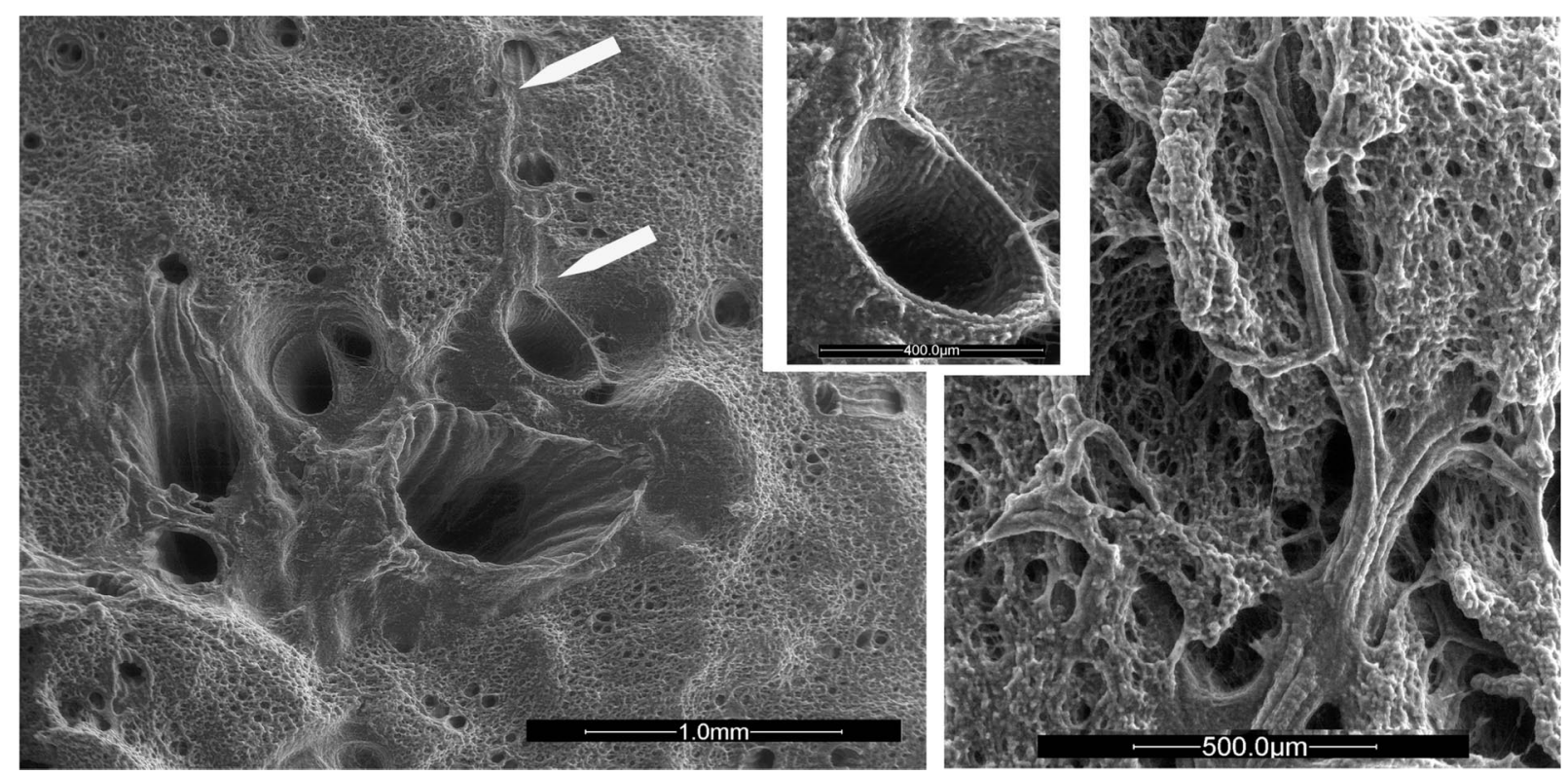

Fig. 2. Photomicrographs (scanning electron microscopy) of the left lung (transverse section of the diaphragmatic lobe) in a control lamb fetus. Left: the pulmonary parenchyma contained uniformly distributed, nonexpanded alveoli with corrugated bronchi, and thin pulmonary arteries and arterioles. Supernumerary arteries arise orthogonally from conventional PA (details in inset) and connect P arteries and veins (white arrows) to achieve a pulmonary arteriovenous shunting. Right: conventional PA and airways with concomitant divisions are closely associated up to late branching in distal capillary network adjacent to alveoli. 
forward flow in the aortic isthmus during systole and diastole progressively decreases (54). This finding has been attributed to the increasing preponderance of the RV output and the leveling of the placental vascular resistance as cerebral vascular resistance progressively declines $(17,20,29,30,40,54)$. During the cardiac cycle, a brief end-systole reversal of the isthmic flow velocity profile occurs and steadily increases as gestation progresses $(20,32,33,54)$. Late systolic flow reversal and admixture come from both the isthmus and DA as a result of reflux caused by the delayed onset and prolonged higher acceleration of the ductus flow velocity (54). The ejection and peak flows occur earlier in the pulmonary trunk than in the ascending aorta, whereas the PA peak flow at the aortic end of the DA occurs later than the aortic peak flow. It has been noted that signals in the left PA branch show a brief systolic forward-flow spike followed by late-systolic and -diastolic flow reversal $(16,54)$. The capacitance of the main and branch PA has been implicated in the altered timing of the circulatory events, and the differences might be related to changing vessel diameters (54).

These investigations of the flow velocity led us to the hypothesis that a possible explanation for the slowdown in PA flow waveforms through the main PA and ductus is that the flow enters the pulmonary circulation before returning to the DA and isthmus through reverse pulmonary flows. In this regard, it is interesting to point out that the observation of the onset of flow in LPA before the pulmonary arterial pressure has up to now been considered as a technical artifact $(33,54)$.

Pulmonary artery hemodynamics, which depend on optimal reciprocal endothelial-epithelial cross talk, contribute to optimal alveolarization and angiogenesis during lung development. However, another critical factor for normal development is the degree to which the fetal lungs are expanded by liquid secreted into the future airways and exiting the trachea $(10,15,25,45$, $46,58,59)$. Deflation of the fetal lungs during development results in hypoplastic lungs that are deficient in alveoli and exhibit increased proportions of type II alveolar epithelial cells $(12,45,46,59)$. A number of studies on lung hypoplasia $(2,12$, $34,42,46,53,58,62)$ have assessed the correlation between fetal lung expansion and prolonged impairment of the signaling necessary for terminal vascularization and alveolarization. In the sheep model of surgically created congenital diaphragmatic hernia $(\mathrm{CDH})(34,58,62)$, growth impairment retards development and angiogenesis, especially during the alveolar phase. Reverse flows across the aortic isthmus in combination with reduced blood flow velocities are detectable in the PA of fetuses presenting pulmonary hypoplasia related to $\mathrm{CDH}(31$, 32, 59).

ERA blockade. Alterations in pulmonary vascular reactivity and smooth muscle cell proliferation, in which nitric oxide (NO) and endothelin (ET-1) appear to be key factors, are prominent causes of abnormalities in the pulmonary circulation (for review, see Refs. 6, 41, and 53). In the lamb model, an increased pulmonary blood flow at 1 wk of life has been associated with alterations in ET-1 signaling followed by changes in NO signaling $(6,43)$. Various pharmaceutical agents have been used to successfully decrease PA pressures and resistances in patients (for review, see Refs. 6, 41, and 58). However, even though $\mathrm{CDH}$ can be detected in a fetus by ultrasound, an early intervention is poorly effective without tocolysis $(24,26)$.
Preterm vascular intervention in the fetal lung therefore is a rational approach to enhance the likelihood of survival during the life-threatening period of extrauterine life (26). TZ, a dual ET-1 antagonist that blocks both endothelin types A and B $\left(\mathrm{ET}_{\mathrm{A}}\right.$ and $\left.\mathrm{ET}_{\mathrm{B}}\right)$ receptors, currently is the only ET-1 receptor antagonist that can be delivered systemically in the last week of gestation when vascular and alveolar pulmonary development enters the terminal phase (9). Therefore, we also investigated the contribution of preterm vasoconstricting processes in both situations by evaluating the effect of a dual ERA, pharmacologically designed for intravenous delivery (9). The protocol was applied to control fetuses with normal lung expansion and to experimental lamb fetuses with restricted lung expansion induced by surgically created $\mathrm{CDH}$ (62). Concomitantly, the three-dimensional organization of fetal lungs was investigated under scanning electron microscopy (SEM) (44), with a special focus on the supernumerary vessels considered as pulmonary arteriovenous shunts.

\section{MATERIALS AND METHODS}

Animals and surgical procedures. The Animal Use and Care Committee of the Marseille School of Medicine reviewed and approved all procedures and protocols used in this study that was in compliance with the requirements of the Animal Welfare Act and the Guide for the Care and Use of Laboratory Animals (National Research Council, 1996). Twenty-eight Merinos d'Arles ewes (National Institute of Agricultural Research, Ewe breeding in dry countries, INRA 868, Montpellier, France) were synchronized using intravaginal fluorogestone $(30 \mathrm{mg}$ ) and pregnant mare serum gonadotrophin (400 IU, 14 days later) 3 days before mating. Forty-five days after mating, pregnancy testing was carried out using pregnancy-specific glycoprotein assays. Ewes were enrolled at the rate of two per week throughout the study.

Before surgery, the animals were fasted for $24 \mathrm{~h}$ and anesthetized by a slow infusion of a bolus of pentobarbital sodium $(250 \mathrm{mg})$ in an external jugular vein and a lumbar intrathecal administration of $1 \%$ marcaine $(2 \mathrm{ml})$ as previously described (61). Pentobarbital sodium was titrated to achieve a continuous narcosis throughout the surgical procedure. Six ECG leads and one transcutaneous arterial oxygen saturation/plethysmographic probe (HP78354C) were placed. Animals were ventilated via endotracheal tubing using a controlled oxygen-air mixture. Intravenous (ear and vena cava) and intra-arterial (superficial femoral artery, 6 Fr-introducer sheath, BSC, Natick, MD) lines were placed for perfusion with Ringer lactate solution (15 $\left.\mathrm{ml} \cdot \mathrm{kg} \cdot \mathrm{h}^{-1}\right)$ and endovascular hemodynamic monitoring of heart rate, blood pressure, and oxygen saturation (Mistral monitoring devices, Agilent Technologies) $(38,49,50)$. Aseptic techniques were used and prophylactic antibiotics (penicillin G:streptomycin, $1 \mathrm{~g}$ ) were administered before and after surgery (48). In ewes carrying twins, only one fetus underwent instrumentation.

The diaphragmatic hernia was created under sterile conditions at day 75 as follows (61). A midline abdominal incision was made, and the uterus was externalized. Following a hysterotomy and a local infiltration of $2 \mathrm{ml}$ of $1 \%$ Xylocaine, the fetal lamb's left forelimb was delivered. Via a left thoracotomy (9th intercostal space), the lung was gently reclined and the left hemidiaphragm exposed. After an excision of a 5-mm-diameter patch from the diaphragm, the stomach was pulled into the thorax. After fetal chest closure, the fetus was replaced in the uterine cavity and penicillin G-streptomycin $(1 \mathrm{~g})$ was added to the amniotic liquid. At the end of the procedure, the hysterotomy and abdominal wall (2 layers) were closed.

On the 135th day of gestation, the ewes were reoperated upon using the same anesthetic and monitoring procedures (61). Three pediatric ECG leads were placed on the upper body of the fetus. After a local 
infiltration of lidocaine ( $2 \mathrm{ml}, 1 \%$ solution), the left axillary artery and vein of the delivered left forelimb of the fetus were exposed and ultrathin thick-walled 22-gauge polyvinyl catheters were advanced through the vessels to the ascending aorta and superior vena cava, respectively. A left thoracotomy (5th intercostal space) and pericardial incision (and further suspension) were performed to expose the heart and great vessels (see Fig. 1). Using an appropriate intravenous placement system (Angiocath, Travenol, Deerfield, IL) through pursestring sutures (6/0), 22-gauge polyvinyl catheters were introduced into the LPA and main PA. The catheters were connected to Stöckert SIII CDX III pressure transducers (COBE Cardiovascular, Arvada, CO). A testing of the catheter-transducer system using the flush method showed no secondary resonance peak up to a frequency of $250 \mathrm{~Hz}$ and a low mean damping coefficient $(<0.15 \%)(54,55)$. A 2-Fr Mikro-Tip catheter pressure-transducer probe (SPR-249/Millar Instruments, Houston, TX) was likewise implanted into the left auricle. For the specific requirements of this study, indwelling catheters connected to liquid-filled pressure probes were used to allow for the delivery of drugs in the PA. Identical catheters, i.e., the same model and length $(40 \mathrm{~cm})$, were placed in the PA and aorta to ensure uniform measurements. To rule out the possibility of artifactual decay of the pressure waveform suspected with fluid-filled catheters (54), we checked that the waveforms obtained after generating an R-wave trigger of the ECG were superposable using the CDX III pressure transducers and 1.8-Fr Mikro-Tip transducer (model SPR-612, Millar Instruments). Probes were precisely positioned by fluoroscopic guidance. To measure blood flow, 4- and 6-mm RS ultrasonic flow transducers (Transonics, Ithaca, NY) were placed around the LPA and ascending aorta on the aortic isthmus, i.e., between the DA and brachiocephalic trunk, respectively (see Fig. 1). Catheters were flushed with $2 \mathrm{ml}$ of heparinized saline $(2.5 \mathrm{IU} / \mathrm{ml})$ to avoid a thrombotic obstruction. Control animals underwent only the second procedure on the 135th day of gestation.

Before any measurements, a 20 -min period with continuous pressure and flow monitoring was allowed for hemodynamic stabilization. After the oxygenation status of the fetus was checked, the vascular reactivity in the LPA was investigated in response to ACh $(15 \mu \mathrm{g} / \mathrm{ml}$, $1 \mathrm{ml} / \mathrm{min}, 2 \mathrm{~min}$ infusion) (33), and another 30-min period was allowed for stabilization. Basal hemodynamics parameters were recorded three times for $30 \mathrm{~s}$ before the start of the infusion of TZ (Actelion, Basel, Switzerland) into the LPA $(120 \mu \mathrm{g} / \mathrm{ml}, 555 \mu \mathrm{g} / \mathrm{min}$, overall dose: $3 \mathrm{mg} / 45 \mathrm{~min}$ ). At the end of the experiment, the fetal lamb was euthanized with potassium chloride $(15 \% \mathrm{wt} / \mathrm{vol}, 10 \mathrm{ml})$ and midazolam (20-mg bolus). The fetal heart and lungs were removed and immersed in ph 7.3 buffer solution pending a histological and SEM examination.

Aortic and pulmonary hemodynamics. Analog dimensional and ECG signals were digitized using an ATMIO-16X analog-to-digital converter (16 bits ADC, $1,000 \mathrm{~Hz}$ sampling frequency, National Instruments, Austin, TX) and recorded for at least 50 consecutive cardiac cycles (standard recording time, $30 \mathrm{~s}$ ) using a customized data capturing window in the Lab View 7.0 software (National Instruments) $(5,38,39,48,50)$. Throughout the experiment, a parallel acquisition of processed and raw data from each input channel was performed using an iox 2 data acquisition and analysis system (EMKA Technologies, Falls Church, VA). The cycle-to-cycle wave variability was overcome by generating a steady-state cycle (256 points) from the time-averaged $\mathrm{P}$ and $\mathrm{Q}$ cardiac cycles calculated using linear interpolation according to the following formula:

$$
\text { Mean period } T=\frac{1}{N_{\mathrm{c}} f} \sum_{j=1}^{N_{\mathrm{c}}} N_{j}
$$

where $N_{j}$ is the number of points within each cardiac cycle, $N_{\mathrm{c}}$ is the number of cycles, and $f$ is the sampling frequency. A mathematical modeling of the discrete $\mathrm{P}$ and $\mathrm{Q}$ signal waves was then performed to obtain the respective $\Omega_{\mathrm{P}}(t)$ and $\Omega_{\mathrm{Q}}(t)$ analytical functions after the fractionation of curves into successive segments separated by two opposite extreme points scaled to measured values offset in the two-dimensional coordinate axis and settling into an increasing or decreasing nature of the waveform segment. In the basic mathematical model, the curve is considered as the second derivative of a sigmoidal function and extracted the elementary segment between the minimum and maximum. The initial waveform was synthesized by summing individual segments and fitting the curve to the original pulse wave so as to obtain the error that was treated in the same manner. The final $\Omega_{\mathrm{P}}(t)$ and $\Omega_{\mathrm{Q}}(t)$ analytical functions corresponded to the sum of the serial functions. The model was applied to both the P and Q waves. The quadratic error normalized to the original waveforms was low regardless of the experimental conditions.

The mean hemodynamics of the $\mathrm{P}$ and $\mathrm{Q}$ waves were calculated as the systolic (maximum), diastolic (minimum), pulsatile $(\Delta=\mid \max -$ $\min \mid$ ), and mean values from their respective $\Omega_{\mathrm{P}}(t)$ and $\Omega_{\mathrm{Q}}(t)$ functions. The results were expressed as millimeters of mercury and milliliters per minute. The algebraic mean pressure $(\bar{P})$ and flow $(\bar{Q})$ values were calculated according to the following formulas:

$$
\overline{\mathrm{P}}=\frac{1}{T} \int_{0}^{T} \Omega_{\mathrm{P}}(t) \mathrm{d} t \quad \text { and } \quad \overline{\mathrm{Q}}=\frac{1}{T} \int_{0}^{T} \Omega_{\mathrm{Q}}(t) \mathrm{d} t
$$

respectively, where $T$ is the mean cardiac cycle period value.

The parametric equations of hysteresis loop for P-Q relationships were defined as follows:

$$
\left\{\begin{array}{c}
X=\Omega_{\mathrm{P}}(t), \\
Y=\Omega_{\mathrm{Q}}(t) .
\end{array} \quad 0 \leq t \leq T\right.
$$

Peripheral_resistance $\left(R_{\mathrm{p}}\right.$, in $\left.\mathrm{mmHg} \cdot \mathrm{ml}^{-1} \cdot \min \right)$ and mean input impedance $\left(\bar{Z}_{\mathrm{e}}, \mathrm{mmHg} \cdot \mathrm{ml}^{-1} \cdot \mathrm{min}\right)$ were calculated according to the following formulas, respectively:

$$
R_{\mathrm{P}}=\frac{\overline{\mathrm{P}}}{\overline{\mathrm{Q}}} \quad \text { and } \quad \bar{Z}_{\mathrm{e}}=\frac{\Delta \mathrm{P}}{\Delta \mathrm{Q}}\left(\Delta \mathrm{P}=\mathrm{P}_{\max }-\mathrm{P}_{\min }, \Delta \mathrm{Q}=\mathrm{Q}_{\max }-\mathrm{Q}_{\min }\right)
$$

The instantaneous $Z_{\mathrm{e}}\left(\bar{Z}_{\mathrm{e}}\right.$, in $\left.\mathrm{kN} \cdot \mathrm{s} \cdot \mathrm{m}^{-5}\right)$ during the cardiac cycle was calculated as the ratio of the function of the pressure and flow according to the following formula:

$$
Z_{\mathrm{e}}=\frac{\Omega_{\mathrm{P}}(t)}{\Omega_{\mathrm{Q}}(t)}=\frac{\sum_{k=0}^{2} \xi_{\mathrm{P}_{k}}}{\sum_{k=0}^{2} \xi_{\mathrm{Q}_{k}}}
$$

Scanning electron microscopy. Electron microscopy using a Quanta 200 SEM (FEI, Eindhoven, The Netherlands) was performed on the fetal heart and lungs that were removed at the end of the experiment and stored in $10 \%$ formalin (44). Specimens were prepared as follows. After being rinsed with the fixative solution, the surgical specimens were fixed for another $48 \mathrm{~h}$. Block samples of the diaphragmatic and cephalic pulmonary lobes were made and further fixed for $24 \mathrm{~h}$ before being cut into 3 -mm serial sections. The sections were submitted to sputter coating with a $30-\mathrm{nm}$ gold layer with or without prior dehydration in progressive alcohols (low vacuum mode, 1 Torr with water vapor).

Statistical analysis. Data treatment and statistical analyses were performed using Systat 10.0 software (SPSS, Chicago, IL). Results were expressed as means \pm SD unless otherwise specified. An analysis of variance was performed with either the Kruskall-Wallis nonparametric test (Scheffé's post hoc test) or the Mann-Whitney test when there are only two groups (49). 


\section{RESULTS}

Technical outcome. A total of 21 fetuses, including 14 control and $7 \mathrm{CDH}$ fetuses, completed the entire protocol by fulfilling the required inclusion criteria. Eleven fetuses were excluded because of ischemic status (7 cases), weak vascular reactivity to ACh (2 cases), and surgically provoked bleeding ( 2 cases). Weight gain was lower in $\mathrm{CDH}$ fetuses than in control fetuses $(2.42 \pm 0.24$ vs. $3.08 \pm 0.32 \mathrm{~kg} ; P<0.01)$. Preprocedural blood gas tension, postprocedural blood gas tension, and $\mathrm{pH}$ in the superior caval vein in $\mathrm{CDH}$ fetus versus controls were as follows: $\mathrm{Po}_{2}, 20.32 \pm 4.67$ versus $19.10 \pm$ $4.47 \mathrm{mmHg} ; \mathrm{PCO}_{2}, 48.98 \pm 7.61$ versus $51.82 \pm 7.61 \mathrm{mmHg}$; and $\mathrm{pH} 7.25 \pm 0.06$ versus $7.22 \pm 0.11(P>0.1)$. There was no significant difference in heart rate between $\mathrm{CDH}$ fetuses and controls (overall mean baseline heart rate, $161 \pm 14$ beats/min).

SEM findings in the left lung. In controls, photomicrographs of the left lung (Fig. 2) demonstrated normal long PA branches alongside the airways, and alveoli were nonexpanded and uniformly distributed throughout the lung. Supernumerary vessels were identified arising orthogonally from the PA between the normal long branches. These vessels supplied the capillary arterial bed in the immediate vicinity of the PA branch from which they arose. A surface tridimensional examination also showed that some supernumerary vessels allowed the direct venous admixture by creating a network of connections between 100- and 500- $\mu \mathrm{m}$ PA branches and similarly sized veins. The supernumerary vessels anatomically can result in iPAVS that may potentially exclude alveoli from the PA blood flow.

In CDH fetuses (Fig. 3), SEM demonstrated clear evidence of an impaired development of alveolar and vascular structures in the left lung. Some PA branches were severely thickened and opened, and adjacent bronchi were embedded within nonvascularized regions with proliferating parenchymal cells showing no alveolar organization. The degree of impairment was variable with regions showing persistent vascularization and alveolarization but with substantial disorganization compared with controls. Intimal proliferation, splitting of elastic laminae, medial and adventitial hyperplasia, and thickening were characteristic features of PA remodeling. The areas of neoangiogenesis and bronchiogenesis with the underdeveloped and interlaced dead-end tubes were consistently observed in the less impaired regions of the hypoplastic lung. No iPAVS was detectable in the hypoplastic lung.

Phasic hemodynamics in the controls. The pulsatile pressure range in both the fetal PA and AO was not incidental. Indeed, although mean pressure values were not significantly higher in the PA than in the AO, the minimal and pulse pressures in the $\mathrm{PA}$ and AO were identical. This finding strongly indicates that vascular compliances were elevated in both vascular beds (Table 1). The isthmic pulsatile pressure profile consistently showed a symmetric sine contour centering on the systolic peak that accounted for $77 \pm 6 \%$ of the cardiac cycle (Fig. 4). In contrast, the systolic flow peak preceded the systolic pressure peak and the ensuing post-systolic flow consisted of a marked backward flow. The isthmic $\bar{Z}_{\mathrm{e}}$ profile showed that most of the aortic flow encountered low forward phasic impedance. The forward impedance associated with the aortic pressure-ascending phase was framed by two impedental events having asymptotic boundaries, whereas the diastolic phasic impedance was negative. The boundaries were mathematically attributable to changes in flow direction: the end

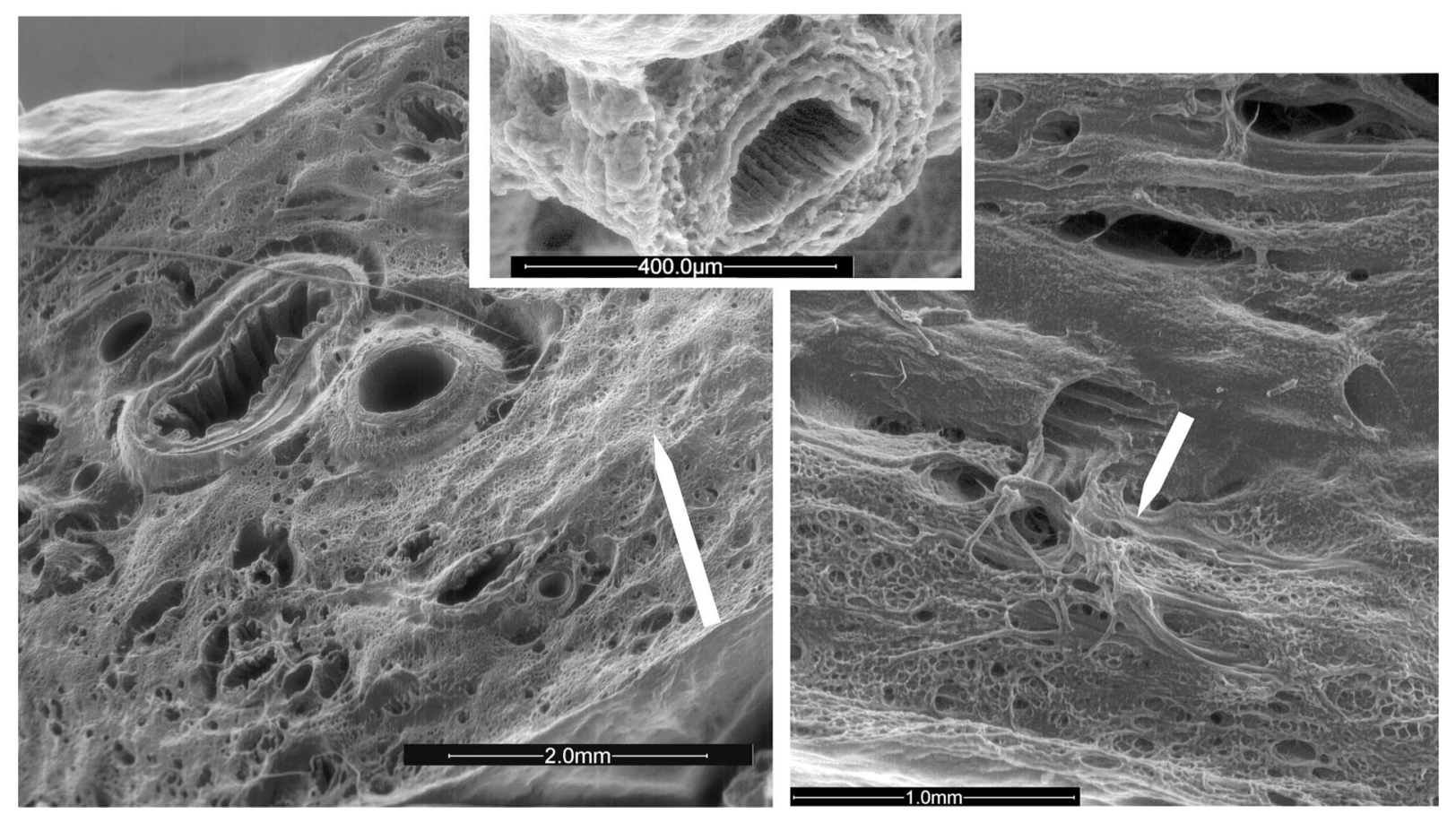

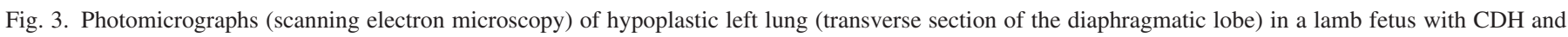

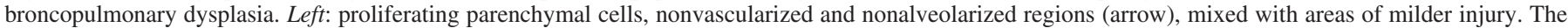

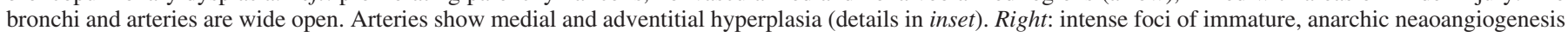
(arrow), neobronchiogenesis, and alveolarization. 


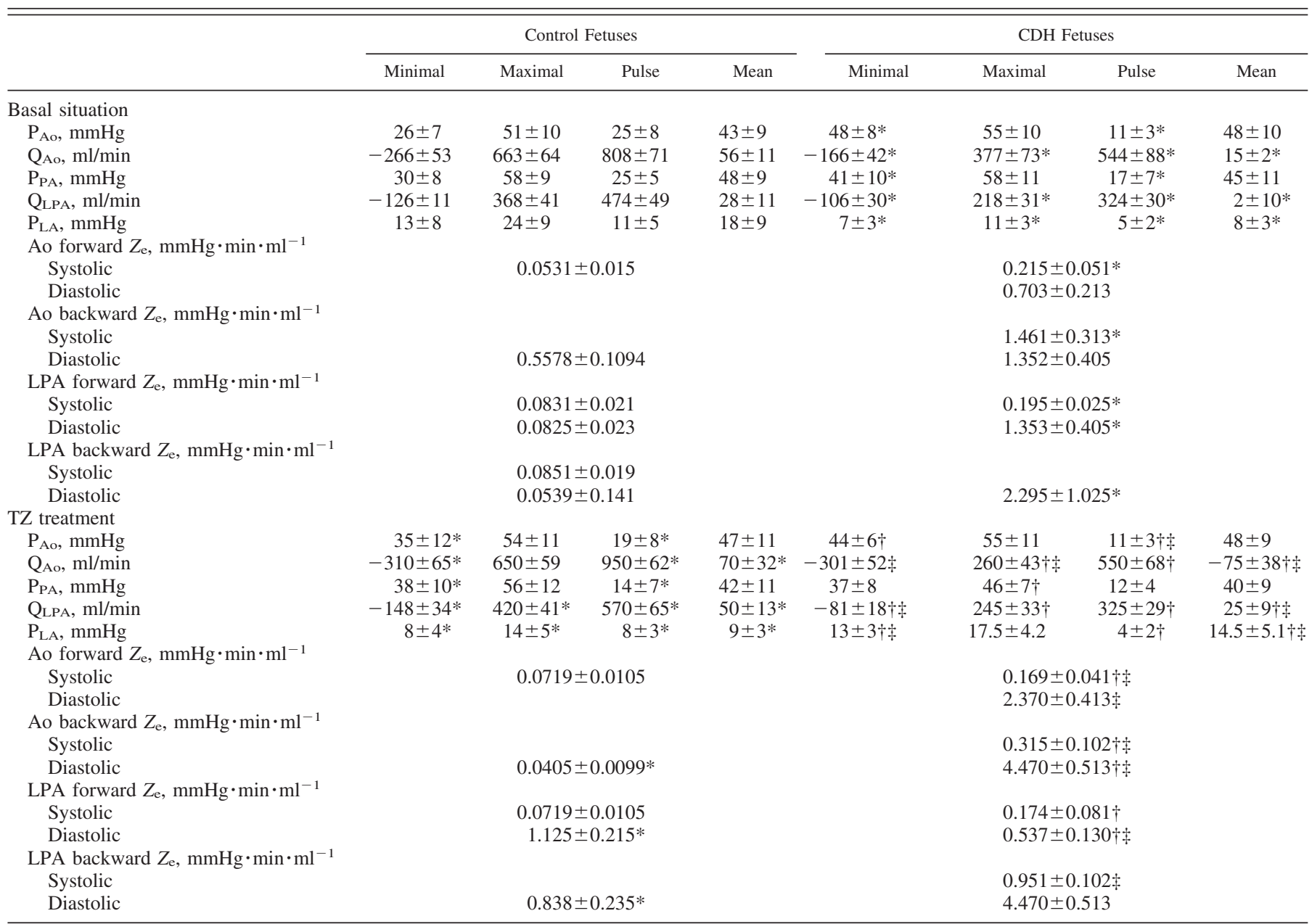

Values are means $\pm \mathrm{SD} ; n=10$ control and 7 congenital diaphragmatic hernia $(\mathrm{CDH})$ fetuses. P, pressure; Q, flow; $Z_{\mathrm{e}}$, entry impedance; Ao, aorta; PA, pulmonary artery; LPA, left PA; LA, left atria; TZ, tezosentan. $* P<0.01$ vs. control under basal situation; $\dagger P<0.01$ vs. control after TZ treatment; $\ddagger P<0.01$ vs. CDH-broncopulmonary dysplasia basal situation.

systolic $\bar{Z}_{\mathrm{e}}$ change coincided with the decrease in systolic flow, and reversal occurred when the zero-flow value was reached. The values showed the opposite pattern when the diastolic backward flow changed to the early systolic forward flow. The flow-pressure hysteresis loop depicted how the increasing aortic systolic flow accompanied by increased pressure in the aorta reached its maximum value early in the cardiac cycle. The maximum pressure was associated with the end of the forwardflow segment. The reversal of isthmic flow provided the energy necessary to supply blood to the cephalic and coronary arteries.

In contrast with the biphasic profile observed in the aortic circulation, the PA hemodynamics were more complex. The PA systolic pressure peak (lasting $31 \pm 6 \%$ of the cardiac cycle) displayed a transient shoulder that was synchronous with PA systolic flow and occurred before the isthmic pressure peak. The diastolic PA pressure peak that was synchronous with the late left auricular pressure peak was no longer detectable in the pulmonary wedge pressure profile, being a reaction to left auricular contraction and emptying. The pulsatile LPA flow consisted of three consecutive forward peak waves interspersed with a substantial reverse flow. The sharp PA ejection peak generated the early shoulder on the systolic pressure peak. Reverse flows were synchronized with the systolic and diastolic peaks. The diastolic peak was induced by left auricular pressure rise. The PA $Z_{\mathrm{e}}$ profile showed a series of impedental events delineated by asymptotic boundaries. The PA $Z_{\mathrm{e}}$ profile showed that $Z_{\mathrm{e}}$ against forward PA flow was 10 times lower than $\bar{Z}_{\mathrm{e}}$ against reverse PA flow. The flow-pressure hysteresis loop showed that LPA flow reached its maximum when PA pressure was at only $10 \%$ of maximum and then abruptly dropped to zero-flow status. The decreasing PA pressure period was associated with the backward flow except during the middiastolic forward-flow segment corresponding to left auricular loading before a contraction.

Phasic hemodynamics in $\mathrm{CDH}$ fetuses. Although still a symmetric systolic peak centered on the cardiac cycle, the aortic pressure waveform in $\mathrm{CDH}$ fetuses was drastically flattened due to elevated $\mathrm{P}_{\mathrm{Ao} \text { min }}$ and decreased pulse pressure, whereas $P_{\text {Ao max }}$ remained constant (Table 1 and Fig. 5). The phasic component of the pressure driving systemic blood flow fell $50 \%$ and, consequently, the pulsatile-to-static hemodynamic ratio changed from 1:1 to $1: 4$ in $\mathrm{CDH}$ fetuses. These hemodynamics changes were highly detrimental to reverse 

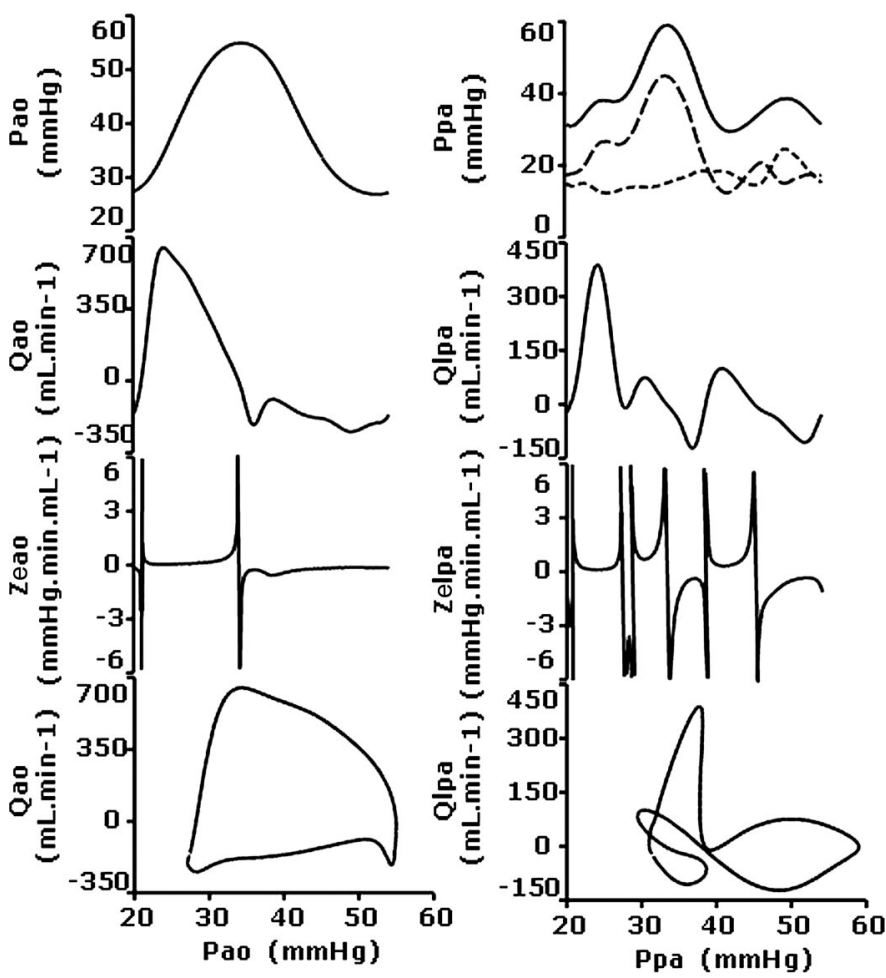

Fig. 4. Pulsatile aortopulmonary hemodynamics in the control fetuses under basal conditions. Plots correspond to population-averaged pulsatile profiles throughout the cardiac cycle along with respective P-Q hysteresis loops. P, pressure; $\mathrm{Q}$, flow; $Z_{\mathrm{e}}$, entry impedance.

flows: the isthmic flow profile showed a major redistribution of forward-flow throughout the cardiac cycle. The ventricular systolic flow peak lasted $41 \pm 5 \%$ of the cardiac cycle, and the forward diastolic peak was strong enough to cross over the zero-flow value. Isthmic $\bar{Z}_{\mathrm{e}}$ was dramatically higher during both systole and diastole and for both forward and reverse flows. The aortic P-Q loop shifted to the right as a result of increased diastolic pressure. A rapid decrease in pressuredriven systolic forward flow occurred before crossing the zero flow. Reverse flow was transient with the pressure peak and did not resume until telediastole.

In the PA, the higher minimal pressure and lower pulse pressure with no change in systolic pressure resulted in a coalescence of three PA pressure contours into a single systolic peak centered on the cardiac cycle. There was a parallel drop in LPA. Systolic LPA forward flow was prolonged to $8 \pm 2 \%$ of the cardiac cycle, and the second forward-flow peak shifted to the right as a result of the pressure peak coalescence. As the pressure increased in the LPA, the flow turned to a long-lasting diastolic forward flow due to the drastic decrease in the left auricular pressure that accompanied the decreased PA flow. Damped flows encountered dramatically elevated $\bar{Z}_{\mathrm{e}}$, especially the diastolic forward flow that was almost cancelled out by 50 times higher $\bar{Z}_{\mathrm{e}}$. The P-Q hysteresis loop indicated that the LPA flows were restricted to the spindle-shaped systolic forward flow and the curved reverse flow associated with the maximum pressure value. The remaining interspersed half of the cardiac cycle was characterized by near-zero flows.

Pulsatile hemodynamics in the controls treated with TZ. Perfusion of TZ in the LPA for 45 min achieved stabilization after 25 to 35 min (data not shown). Changes in the isthmic hemodynamics included an increase in minimal pressure and reverse flow resulting in a decrease in pulse pressure and an increase in pulse flow (Table 1 and Fig. 6). Asymmetry accompanied the shortening of the systolic aortic pressure peak (lasting $51 \pm 5 \%$ of the cardiac cycle, $P<0.05$ vs. basal value). With no change in forward $Z_{\mathrm{e}}$, systolic isthmic flow peak was reduced by one-fourth and still preceded the systolic pressure peak, contributing to the shoulder on $\mathrm{Q}_{\text {Ao }}$ systolic contour. The diastolic reverse flow increased due to a tenfold decrease in $\bar{Z}_{\mathrm{e}}$ (increase, $\mathrm{Q}_{\text {Ao } \min }>\mathrm{P}_{\text {Ao } \min }$ ). The aortic $\mathrm{P}-\mathrm{Q}$ loop depicts the sharpening effect of TZ perfusion on the initial systolic P-Q slope with the induction of a drastic drop in the $\mathrm{P}-\mathrm{Q}$ slope of the reverse flow plateau that lasted throughout diastole.

After perfusion of $\mathrm{TZ}$, the diastolic pressure in the PA increased, leading to a decrease in the pulse pressure, accompanied by an increase in pulse and mean flow as a result of an increase in both forward and reverse flows. The flow-induced pressure formed an enlarged symmetric peak lasting $68 \pm 6 \%$ of the cardiac cycle ( $P<0.05$ vs. basal value). The enhanced LPA ejection was accompanied by a substantial increase in LPA pulse flow. The first diastolic flow peak that was in the forward direction in controls was converted into a transient lowering of the backward flow. The left auricular loading phase and pressure substantially decreased after TZ perfusion due to the increased backward flow in the PA. The forward and backward flows encountered higher $\bar{Z}_{\mathrm{e}}$ due to a coalescence of previously separated impedental events. The hysteresis loop shifted to the right due to the increased diastolic pressure and clearly demonstrated that the forward flow was due solely to
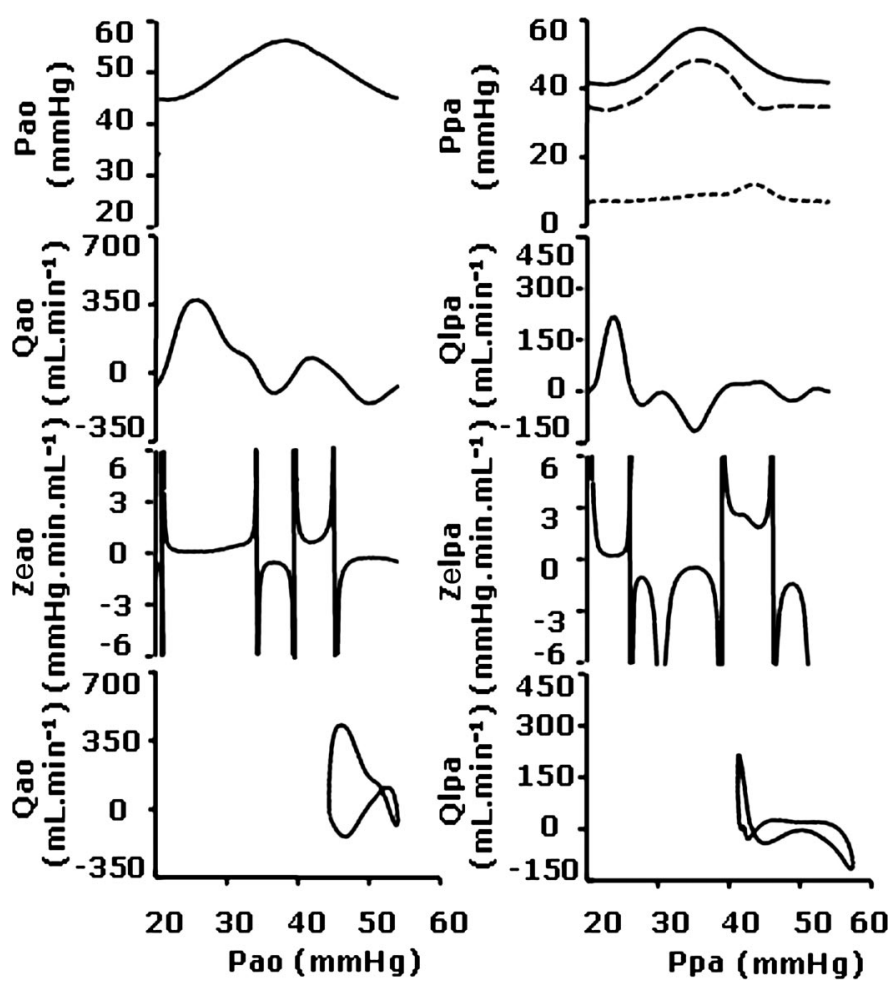

Fig. 5. Pulsatile aortopulmonary hemodynamics in fetuses with $\mathrm{CDH}$ and PVD under basal conditions. Plots correspond to population-averaged pulsatile profiles throughout the cardiac cycle along with respective P-Q hysteresis loops. 


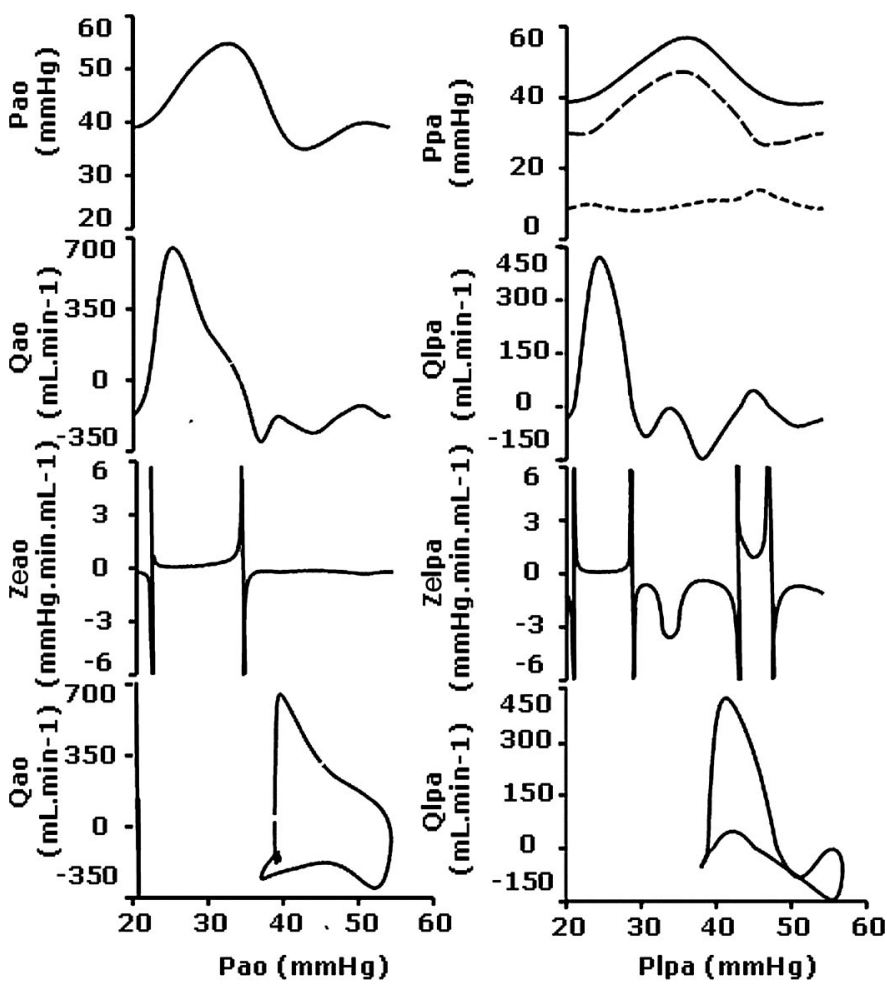

Fig. 6. Pulsatile aortopulmonary hemodynamics in the control fetuses after tezosentan perfusion (45 $\mathrm{min}$ ). Plots correspond to population-averaged pulsatile profiles throughout the cardiac cycle along with respective P-Q hysteresis loops.

the enhancement of the systolic peak flow and higher relief in the late diastolic phase. The systolic flow began at a low threshold of diastolic reverse flow and provided more energy for the ensuing systolic forward flow.

Pulsatile hemodynamics in $\mathrm{CDH}$ fetuses treated with $\mathrm{TZ}$. After TZ perfusion, the mean isthmic flow reversed due to a marked decrease in the systolic forward flow accompanied by a twofold increase in the reverse flow (Table 1 and Fig. 7). The enhancement of the systolic forward flow was immediately followed by a drastic increase in the reverse flow that progressively returned to a low-grade forward plateau. The diastolic forward $\bar{Z}_{\mathrm{e}}$ increased markedly. The aortic P-Q hysteresis loop demonstrated that that the early systolic forward flow peak was held at a plateau for a longer time but at a lower level. When the maximum pressure was reached, the plateau suddenly changed into an amplified reverse flow before returning to an almost completely forward flow throughout diastole.

After TZ perfusion, the CDH-induced flattening of the systolic pressure peak in the PA was shorter in duration (lasting $55 \pm 3 \%$ of the cardiac cycle). The mean flow was in a forward direction and increased due to a marked increase in the diastolic forward flow. The enhancement of systolic forward impedance was noticeable due to a drastic decrease in the impedental events throughout the remaining cardiac cycle. When compared with baseline, the P-Q hysteresis loop clearly showed an increase in the magnitude of the forward systolic peak and a marked enhancement in both the duration and magnitude of diastolic reverse flow.

\section{DISCUSSION}

This study assessed the pressure and flow wave relationships in near-term fetal lambs. These waves were modeled into parametric phasic hemodynamics synchronized with an R-peak trigger of the ECG with anterograde flow being zeroed and positive, the reverse flow being negative, and the "reverse" impedance (a term devoid of physical meaning) being defined as the impedance encountered by reverse flow. The specific sites of investigation (see Fig. 1) were the aortic isthmus and LPA in the aorta-PA-DA fetal vascular network. This anatomically complicated network is interconnected by central cardiac shunts and presents large outlets, i.e., the supraaortic/brain/coronary arteries and thoracic aorta/placenta as well as middle-sized tributary effluents, i.e., the PA branches $(3,4,8,10,34,63)$.

The most outstanding finding in control fetuses was that the energy required for blood circulation was supplied in a sequential manner by two components. The first component involved the synchronous aortic and pulmonary systolic flow waves (kinetic energy) produced by biventricular cardiac ejection. The second component involved a recoil of compliant arterial walls following respective flow-related distension pressure waves (potential energy) $(5,38,39,48,50)$. A unique feature of fetal pulmonary arterial circulation is that phasic, pulsatile hemodynamics is equivalent to static hemodynamics. The systolic pressure peak generated by prominent right ventricle ejection encounters low phasic arterial impedance and is synchronized with reverse LPA flow that is highly sensitive to left auricular events due mainly to efficient PAVS (28). The same results were previously obtained in the preterm fetal lamb by
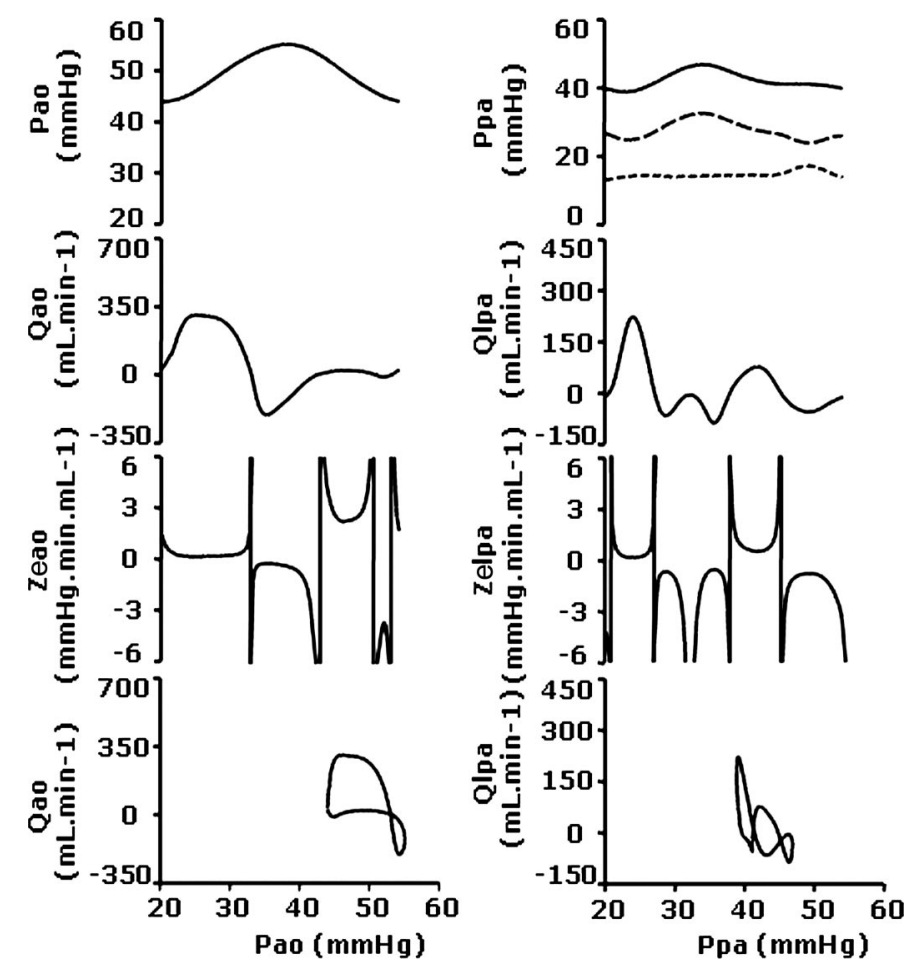

Fig. 7. Pulsatile aortopulmonary hemodynamics in fetuses with $\mathrm{CDH}$ and PVD after tezosentan perfusion (45 $\mathrm{min}$ ). Plots correspond to populationaveraged pulsatile profiles throughout the cardiac cycle along with respective P-Q hysteresis loops. 
invasive measurements of pressure and flow with "manual" postsynchronization to the R wave of the ECG $(33,54)$. The first hypothesis of this study was that phasic PVR has been overestimated. Our data show that weak fetal pulmonary perfusion is not accounted for by elevated PVRs. Indeed, an analysis of phasic hemodynamics (i.e., $50 \%$ of the pulsed flow vs. static component) revealed that the $Z_{\mathrm{e}}$ in PA branches was low. The contributing components are a substantial reflux from the LPA (and other PA branches) to the DA and aortic isthmus and functional iPAVS. The potential impact of iPAVS on pulmonary hemodynamics is supported by high sensitivity to atrial events elicited by flow in the PA and its branches $(21,23$, 28, 29, 63).

Our second hypothesis was that a reverse pulmonary flow ultimately directed into the isthmus promoted forward cerebral and coronary blood flow in the later stages of the cardiac cycle. This would potentially be more energy efficient since the pressure wave generated by the outgoing blood was used to propel the isthmic flow. In addition, this flow distribution would prevent oxygen-depleted visceral blood in the descending aorta from reaching the cerebral and coronary arteries.

The data in $\mathrm{CDH}$ fetuses revealed that the static component of the pulmonary circulation became dominant over the phasic component. The pressure-driven phasic component of biventricular ejection was reduced by $50 \%$ (pulsatile-to-static ratio, $1: 4)$. The RV and LV ejection volume markedly decreased, but cardiac shunting prevented the blood pressure from rising $(1,3$, $4,22,23)$, and the well-documented increase in arterial impedance was observed in the hypoplastic lung. These hemodynamic changes were detrimental for the reverse flows, and the isthmic flow changed to the forward direction during diastole. This response was physiologically appropriate to preserve brain oxygenation since maintaining the reverse flow such as the reverse pulmonary flow decreased would have required the reverse isthmic flow from the descending aorta and visceral circulation. Our results indicated that the blood flowing to the coronary and brain arteries was slowed but not contaminated by poorly oxygenated blood. It was estimated that the drop in the amount of oxygenated blood reaching the brain was $<50 \%$.

The contributing factors to diminished pulmonary flows included morphometric (and functional) PA alterations and the presence of nonvascularized regions with proliferating parenchymal cells showing no alveolar organization. These factors were enhanced by the absence of iPAVS and increased sensitivity to left auricular hemodynamics $(14,34,61,63)$. The observation of an asynchronous decrease in kinetic and subsequent potential energies in $\mathrm{CDH}$ fetuses supported the prominence of flow changes over pressure changes and suggests a cardiac origin. A poor propulsion of the aortopulmonary blood flow was attributed to a combination of concomitant factors including decreased cardiac output, damping of pressure waves and pulsatility, and heightened phasic impedance. The shortening and damping of the systolic flow waveform are in agreement with previous studies in the developing heart, showing that chronic pulmonary insufficiency causes global cardiac dysfunction, e.g., an impairment of functional reserve and myocardial contractility, but that diastolic function was preserved $(23,28)$. In clinical settings, neonates with $\mathrm{CDH}$ have a much higher prevalence of cardiac defects than normal infants and a lowered LV-to-RV ratio correlates a poor outcome and pulmonary hypertension $(24,32,60)$. These results strongly advocate a therapeutic strengthening of the failing cardiac function that may recover with the restoration of the appropriate PA flow. Specifically, it may be of therapeutic importance to determine whether or not the $\mathrm{CDH}$-induced changes in the reverse flows are related to the changes in ventriculo-arterial coupling and thereby to LV-to-RV-ratio lowering.

Our findings in preterm fetuses indicate that experimental $\mathrm{CDH}$ had a greater impact on pulmonary flow than on pulmonary pressure. Previous investigations of the effects of prolonged tracheal obstruction (TO) and subsequent increased lung expansion on pulmonary hemodynamics in fetal sheep showed that an equalization of intraluminal pressure markedly increased pulmonary flow in TO fetuses $(45,46,59)$. Most changes in the pulmonary flow waveform occurred during diastole with few changes during systole. The diastolic pulmonary flow was mainly responsible for generating the backward compression and expansion waves that interact with the pulmonary vascular bed to cause retrograde flow $(23,29,45,46)$. Knowing the extent of the impact on backward flow caused by the enhancing effect of TO on the forward flow and by the increased luminal pressure related to liquid filling might be of critical importance for therapeutic decision making. In regard to therapy to restore impaired pulmonary circulation in the hypoplastic lung, a potentially interesting finding of our study was the presence of an intense foci of neoangiogenesis and bronchiogenesis with interlaced immature and dead-end tubes in less disorganized regions of the lung. The epithelial cells in distal airspaces of the fetal lung expressed VEGF, suggesting that the epithelium might regulate a temporal and spatial development of alveolar capillaries $(25,53,58,61)$. Since VEGF is considered as an endothelial cell survival factor that can improve oxygen and cytokine injury $(25,53,62)$, it is tempting to speculate that the aberrant angiogenesis represents an attempt by the still-organized alveolar cells to restore the appropriate vascularization through persistent VEGF secretion.

Signaling pathways mediating the pulmonary vascular response that was either impaired in the hypoplastic lung or heightened in the case of hypertension have still not been clearly defined (for review, see Refs. 53 and 58). In control fetuses, we observed that endothelin receptor (ER) blockade had a slight favorable effect on the forward flow in both the aorta and LPA, whereas it drastically enhanced the backward flow during the prolonged diastolic period. The net effect of these two changes was a decrease in left auricular pre- and postloading. Forward flow was favored during systole in the aorta and during diastole in the PA where decreasing vascular impedance enhanced back pumping from the pulmonary circulation. The consequences of TZ perfusion on both forward and backward flow were correlated with the changes in cardiac cycle (e.g., shortening of systolic duration) and arterial effects (e.g., vascular wall stiffness and elasticity), respectively. These hemodynamic effects were likely mediated by NO: recent findings in juvenile lambs demonstrated that the increase in mean blood flow observed in TZ-treated lambs was due to an increase in NO synthase activity in lung tissue that was not observed in control lambs (42).

Our observation of a drastic 10-fold decrease in aortic impedance after TZ perfusion was consistent with the presence of ET receptors in the aorta $(11,41)$. Similarly, the TZ effects in the PA were consistent with a different spatial distribution of the ER along the pathway as well as with the differences in the 
responses of $\mathrm{ET}_{\mathrm{A}}$ and $\mathrm{ET}_{\mathrm{B}}$ receptors to ET-1 (9). The vasoconstricting properties of ET-1 were inhibited in the proximal segments of the PA where $\mathrm{ET}_{\mathrm{A}}$ receptors are predominant (11, 41,62 ). In distal segments of the PA where $\mathrm{ET}_{\mathrm{B}}$ receptors that mediate vasodilatation through activation of the $\mathrm{NO} /$ prostanoid signaling system are predominant, TZ strongly enhanced the forward flow during diastole. Since forward diastolic flow is dependent on vasodilatation in smaller PAs, this finding strongly supported the view that acute TZ perfusion did not elicit the vasoconstricting effects associated with $\mathrm{ET}_{\mathrm{B}}$ receptor blockade $(9,41)$.

In $\mathrm{CDH}$ fetuses the hemodynamic effects of ER blockade were limited to a slight increase in forward flow during systole in the aorta and during diastole in the PA. The mechanisms regulating these processes mainly involved a decrease in the corresponding impedances. The pharmacological effects of ERAs in CDH fetuses were unclear. Previous studies have provided contrasting evidence. One study showed that the $\mathrm{ET}_{\mathrm{B}}$ receptor agonist sarafotoxin had no effect, whereas another showed that the $\mathrm{ET}_{\mathrm{A}}$ receptor antagonist $\mathrm{BQ}-123$ caused a greater pulmonary vasodilatation in the $\mathrm{CDH}$ than in the control animals $(42,61)$. The findings that $\mathrm{TZ}$ was inefficient for acute blockade of $\mathrm{ET}_{\mathrm{A}}$ receptors in lamb fetuses with $\mathrm{CDH}$ argued against the intravenous administration of soluble mixed ET-1 receptor antagonists to improve the hypoplastic lung perfusion.

The present results have a number of therapeutic implications. Together with functionally correct iPAVS, the backward flow in the PA is a physiological necessity to protect the pulmonary circulation from the right heart stream and, conversely, to supply blood to the fetal brain and placenta during the diastole. Since these backward flows must change to forward flows by the time of DA closure at birth, they may be deleterious in the case of impaired pulmonary vasculature, e.g., in $\mathrm{CDH}$ fetuses. Pulmonary hypoplasia occurs early in development when the lung is still in the terminal air sac phase and when growth retardation continues into the final $2 \mathrm{wk}$ of gestation when the lung enters the alveolar phase. From a therapeutic point of view, it is unrealistic to hope for the recovery of the pulmonary proliferation in nonvascularized, nonalveolarized regions. On the other hand, less affected regions showing signs of neoangiogenesis and alveolarization, even anarchic in nature, can be therapeutic targets, especially for attempting to initiate backward-to-forward conversion of pulmonary flows. As mentioned above, the hemodynamic effect of TO should be investigated with regard to forward-backward flow conversion. The poor effectiveness of ER blockade is disappointing. A possible alternative therapeutic approach to achieve hemodynamic objectives in addition to restoring vascularization and alveolarization in moderately affected pulmonary regions might consist of the implanting of a flow wave-filtering device (possibly resorbable) in the PA $(5,50)$. The purpose of such a device would be to restore the forward blood flow through the PA by blocking the backward flow. Further studies to design such a device are needed.

\section{REFERENCES}

1. Anderson DF, Bissonnette JM, Faber JJ, Thornburg KL. Central shunt flows and pressures in the mature fetal lamb. Am J Physiol Heart Circ Physiol 241: H60-H66, 1981.
2. Balasubramaniam V, Maxey AM, Fouty BW, Abman SH. Nitric oxide augments fetal pulmonary artery endothelial cell angiogenesis in vitro. Am J Physiol Lung Cell Mol Physiol 290: L1111-L1116, 2006.

3. Bennett SH, Eldridge MW, Zaghi D, Zaghi SE, Milstein JM, Goetzman BW. Form and function of fetal and neonatal pulmonary arterial bifurcations. Am J Physiol Heart Circ Physiol 279: H3047-H3057, 2000.

4. Bennett SH, Goetzman BW, Milstein JM, Pannu JS. Role of arterial design on pulse wave reflection in a fractal pulmonary network. $J$ Appl Physiol 80: 1033-1056, 1996.

5. Berry JL, Manoach E, Mekkaoui C, Rolland PH, Moore JE, Rachev A. Hemodynamics and wall mechanics of a compliance matching stent: in vitro and in vivo analysis. J Vasc Interv Radiol 13: 97-105, 2002.

6. Black SM, Kumar S, Wiseman D, Ravi K, Wedgwood S, Ryzhov V, Fineman JR. Pediatric pulmonary hypertension: roles of endothelin-1 and nitric oxide. Clin Hemorheol Microcircul 37: 111-120, 2007.

7. Bonnin P, Fouron JC, Teyssier G, Sonesson SE, Skoll A. Quantitative assessment of circulatory changes in the fetal aortic isthmus during progressive increase of resistance to umbilical blood flow. Circulation 88: 216-222, 1993.

8. Burrowes KS, Hunter PJ, Tawhai MH. Anatomically based finite element models of the human pulmonary arterial and venous trees including supernumerary vessels. J Appl Physiol 99: 731-738, 2005.

9. Clozel M, Ramuz H, Clozel JP, Breu V, Hess P, Loffler BM, Coassolo P, Roux S. Pharmacology of tezosentan, new endothelin receptor antagonist designed for parenteral use. J Pharmacol Exp Ther 290: 840-846, 1999.

10. Dawson CA, Krenz GS, Karau KL, Haworth ST, Hanger CC, Linehan JH. Structure-function relationships in the pulmonary arterial tree. J Appl Physiol 86: 569-583, 1999.

11. De Lagausie $P$, de Buys-Roessingh A, Ferkdadji L, Saada J, Aisenfisz S, Martinez-Vinson C, Fund X, Cayuela JM, Peuchmaur M, Mercier JC, Berrebi D. Endothelin receptor expression in human lungs of newborns with congenital diaphragmatic hernia. J Pathol 205: 112-118, 2005.

12. Dukarm RC, Steinhorn RH, Russell JA, Lakshminrusimha S, Swartz D, Cummings JJ. Selective type 5 phosphodiesterase inhibition alters pulmonary hemodynamics and lung liquid production in near-term fetal lambs. J Appl Physiol 99: 2331-2336, 2005.

13. Eldridge MW, Dempsey JA, Haverkamp HC, Lovering AT, Hokanson JS. Exercise-induced intrapulmonary arteriovenous shunting in healthy humans. J Appl Physiol 97: 797-805, 2004.

14. Fineman JR, Soifer SJ, Heymann MA. Regulation of pulmonary vascular tone in the perinatal period. Annu Rev Physiol 57: 115-134, 1995.

15. Folkesson HG, Chapin CJ, Beard LML, Ertsey R, Matthay MA, Kitterman JA. Congenital diaphragmatic hernia prevents absorption of distal air space fluid in late-gestation rat fetuses. Am J Physiol Lung Cell Mol Physiol 290: L478-L484, 2006.

16. Fouron JC. The unrecognized physiological and clinical significance of the fetal aortic isthmus. Ultrasound Obstet Gynecol 22: 441-447, 2003.

17. Fouron JC, Gosselin J, miel-Tison C, Infante-Rivard C, Fouron C, Skoll A, Veilleux A. Correlation between prenatal velocity waveforms in the aortic isthmus and neurodevelopmental outcome between the ages of 2 and 4 years. Am J Obstet Gynecol 184: 630-636, 2001.

18. Fouron JC, Gosselin J, Raboisson MJ, Lamoureux J, Tison CA, Fouron C, Hudon L. The relationship between an aortic isthmus blood flow velocity index and the postnatal neurodevelopmental status of fetuses with placental circulatory insufficiency. Am J Obstet Gynecol 192: 497503, 2005.

19. Fouron JC, Skoll A, Sonesson SE, Pfizenmaier M, Jaeggi E, Lessard M. Relationship between flow through the fetal aortic isthmus and cerebral oxygenation during acute placental circulatory insufficiency in ovine fetuses. Am J Obstet Gynecol 181: 1102-1107, 1999.

20. Fouron JC, Zarelli M, Drblik P, Lessard M. Flow velocity profile of the fetal aortic isthmus through normal gestation. Am J Cardiol 74: 483-486, 1994.

21. Gao YS, Raj JU. Role of veins in regulation of pulmonary circulation. Am J Physiol Lung Cell Mol Physiol 288: L213-L226, 2005.

22. Giraud GD, Faber JJ, Jonker SS, Davis L, Anderson DF. Effects of intravascular infusions of plasma on placental and systemic blood flow in fetal sheep. Am J Physiol Heart Circ Physiol 291: H2884-H2888, 2006.

23. Grant DA, Hollander E, Skuza EM, Fauchere JC. Interactions between the right ventricle and pulmonary vasculature in the fetus. J Appl Physiol 87: 1637-1643, 1999. 
24. Graziano JN. Cardiac anomalies in patients with congenital diaphragmatic hernia and their prognosis: a report from the Congenital Diaphragmatic Hernia Study Group. J Pediatr Surg 40: 1045-1050, 2005.

25. Grover TR, Parker TA, Balasubramaniam V, Markham NE, Abman SH. Pulmonary hypertension impairs alveolarization and reduces lung growth in the ovine fetus. Am J Physiol Lung Cell Mol Physiol 288: L648-L654, 2005.

26. Hedrick HL, Flake AW, Crombleholme TM, Howell LJ, Johnson MP, Wilson RD, Adzick NS. The ex utero intrapartum therapy procedure for high-risk fetal lung lesions. J Pediatr Surg 40: 1038-1044, 2005.

27. Hislop AA. Airway and blood vessel interaction during lung development. J Anat 201: 325-334, 2002

28. Hollander EH, Dobson GM, Wang JJ, Parker KH, Tyberg JV. Direct and series transmission of left atrial pressure perturbations to the pulmonary artery: a study using wave-intensity analysis. Am J Physiol Heart Circ Physiol 286: H267-H275, 2004.

29. Hollander EH, Wang JJ, Dobson GM, Parker KH, Tyberg JV. Negative wave reflections in pulmonary arteries. Am J Physiol Heart Circ Physiol 281: H895-H902, 2001.

30. Kenny JF, Plappert T, Doubilet P, Saltzman DH, Cartier M, Zollars L, Leatherman GF, St. John Sutton MG. Changes in intracardiac blood flow velocities and right and left ventricular stroke volumes with gestational age in the normal human fetus: a prospective Doppler echocardiographic study. Circulation 74: 1208-1216, 1986.

31. Laudy JA, Gaillard JL, vd Anker JN, Tibboel D, Wladimiroff JW. Doppler ultrasound imaging: a new technique to detect lung hypoplasia before birth? Ultrasound Obstet Gynecol 7: 386-392, 1996.

32. Laudy JA, Tibboel D, Robben SG, de Krijger RR, de Ridder MA, Wladimiroff JW. Prenatal prediction of pulmonary hypoplasia: clinical, biometric, and Doppler velocity correlates. Pediatrics 109: 250-258, 2002.

33. Lewis AB, Heymann MA, Rudolph AM. Gestational changes in pulmonary vascular responses in fetal lambs in utero. Circ Res 39: 536-541, 1976.

34. Lipsett J, Cool JC, Runciman SI, Ford WD, Kennedy JD, Martin AJ, Parsons DW. Morphometric analysis of preterm fetal pulmonary development in the sheep model of congenital diaphragmatic hernia. Pediatr Dev Pathol 3: 17-28, 2000.

35. Makikallio K, Erkinaro T, Niemi N, Kavasmaa T, Acharya G, Pakkila M, Rasanen J. Fetal oxygenation and Doppler ultrasonography of cardiovascular hemodynamics in a chronic near-term sheep model. Am J Obstet Gynecol 194: 542-550, 2006.

36. Makikallio K, Mcelhinney DB, Levine JC, Marx GR, Colan SD, Marshall AC, Lock JE, Marcus EN, Tworetzky W. Fetal aortic valve stenosis and the evolution of hypoplastic left heart syndrome: patient selection for fetal intervention. Circulation 113: 1401-1405, 2006.

37. McMullan DM, Hanley FL, Cohen GA, Portman MA, Riemer RK. Pulmonary arteriovenous shunting in the normal fetal lung. J Am Coll Cardiol 44: 1497-1500, 2004.

38. Mekkaoui C, Friggi A, Rolland PH, Bodard H, Piquet P, Bartoli JM, Mesana T. Simultaneous measurements of arterial diameter and blood pressure to determine the arterial compliance, wall mechanics and stresses in vivo. Eur J Vasc Endovasc Surg 21: 208-213, 2001

39. Mekkaoui C, Rolland PH, Friggi A, Rasigni M, Mesana TG. Pressureflow loops and instantaneous input impedance in the thoracic aorta: another way to assess the effect of aortic bypass graft implantation on myocardial, brain, and subdiaphragmatic perfusion. J Thorac Cardiovasc Surg 125: 699-710, 2003.

40. Mitchell JR, Whitelaw WA, Sas R, Smith ER, Tyberg JV, Belenkie I. RV filling modulates LV function by direct ventricular interaction during mechanical ventilation. Am J Physiol Heart Circ Physiol 289: H549H557, 2005.

41. Motte S, McEntee K, Naeije R. Endothelin receptor antagonists. Pharmacol Ther 110: 386-414, 2006.

42. Oishi P, Azakie A, Harmon C, Fitzgerald RK, Grobe A, Xu J, Hendricks-Munoz K, Black SM, Fineman JR. Nitric oxide-endothelin-1 interactions after surgically induced acute increases in pulmonary blood flow in intact lambs. Am J Physiol Heart Circ Physiol 290: H1922-H1932, 2006.

43. Ovadia B, Reinhartz O, Fitzgerald R, Bekker JM, Johengen MJ, Azakie A, Thelitz S, Black SM, Fineman JR. Alterations in ET-1, not nitric oxide, in 1-week-old lambs with increased pulmonary blood flow. Am J Physiol Heart Circ Physiol 284: H480-H490, 2003.
44. Piquet P, Rolland PH, Bartoli JM, Tranier P, Moulin G, Mercier C. Tantalum-Dacron coknit stent for endovascular treatment of aortic aneurysms: a preliminary experimental study. J Vasc Surg 19: 698-706, 1994.

45. Polglase GR, Morley CJ, Crossley KJ, Dargaville P, Harding R, Morgan DL, Hooper SB. Positive end-expiratory pressure differentially alters pulmonary hemodynamics and oxygenation in ventilated, very premature lambs. J Appl Physiol 99: 1453-1461, 2005.

46. Polglase GR, Wallace MJ, Morgan DL, Hooper SB. Increases in lung expansion alter pulmonary hemodynamics in fetal sheep. J Appl Physiol 101: 273-282, 2006.

47. Reddy VM, Meyrick B, Wong J, Khoor A, Liddicoat JR, Hanley FL, Fineman JR. In utero placement of aortopulmonary shunts. A model of postnatal pulmonary-hypertension with increased pulmonary blood-flow in lambs. Circulation 92: 606-613, 1995.

48. Rolland PH, Charifi AB, Verrier C, Bodard H, Friggi A, Piquet $\mathbf{P}$, Moulin G, Bartoli JM. Hemodynamics and wall mechanics after stent placement in swine iliac arteries: comparative results from six stent designs. Radiology 213: 229-246, 1999.

49. Rolland PH, Friggi A, Barlatier A, Piquet P, Latrille V, Faye MM, Guillou J, Charpiot P, Bodard H, Ghiringhelli O, Calaf R, Luccioni R, Garçon D. Hyperhomocysteinemia-induced vascular damage in the minipig. Captopril-hydrochlorothiazide combination prevents elastic alterations. Circulation 91: 1161-1174, 1995.

50. Rolland PH, Mekkaoui C, Vidal V, Berry JL, Moore JE, Moreno M, Amabile P, Bartoli JM. Compliance matching stent placement in the carotid artery of the swine promotes optimal blood flow and attenuates restenosis. Eur J Vasc Endovasc Surg 28: 431-438, 2004

51. Rudolph AM, Heymann MA. Circulatory changes during growth in the fetal lamb. Circ Res 26: 289-299, 1970.

52. Rudolph AM, Heymann MA. The circulation of the fetus in utero. Methods for studying distribution of blood flow, cardiac output and organ blood flow. Circ Res 21: 163-184, 1967.

53. Said SI. Mediators and modulators of pulmonary arterial hypertension. Am J Physiol Lung Cell Mol Physiol 291: L547-L558, 2006.

54. Schmidt KG, Silverman NH, Rudolph AM. Phasic flow events at the aortic isthmus-ductus arteriosus junction and branch pulmonary artery evaluated by multimodal ultrasonography in fetal lambs. Am J Obstet Gynecol 179: 1338-1347, 1998.

55. Schwid HA. Frequency response evaluation of radial artery cathetermanometer systems: sinusoidal frequency analysis versus flush method. J Clin Monit 4: 181-185, 1988.

56. Shaw AM, Bunton DC, Fisher A, McGrath JC, Montgomery I, Daly C, MacDonald A. V-shaped cushion at the origin of bovine pulmonary supernumerary arteries: structure and putative function. J Appl Physiol 87: 2348-2356, 1999.

57. Sonesson SE, Fouron JC. Doppler velocimetry of the aortic isthmus in human fetuses with abnormal velocity waveforms in the umbilical artery. Ultrasound Obstet Gynecol 10: 107-111, 1997.

58. Stenmark KR, Abman SH. Lung vascular development: implications for the pathogenesis of bronchopulmonary dysplasia. Annu Rev Physiol 67: 623-661, 2005.

59. Tchirikov M, Hecher K, Deprest J, Verbeken E, Roubliova X, Schroder HJ. Pulmonary circulation of fetal sheep with lung hyperplasia following tracheal occlusion. Ultrasound Obstet Gynecol 25: 277-281, 2005 .

60. Thébaud B, Azancot A, de Lagausie P, Vuillard E, Ferkadji L, Benali K, Beaufils F. Congenital diaphragmatic hernia: antenatal prognostic factors. Does cardiac ventricular disproportion in utero predict outcome and pulmonary hypoplasia? Intensive Care Medicine 23: 1062-1069, 1997

61. Thébaud B, de Lagausie P, Forgues D, Aigrain Y, Mercier JC, Tuan AD. ET $_{\mathrm{A}}$-receptor blockade and $\mathrm{ET}_{\mathrm{B}}$-receptor stimulation in experimental congenital diaphragmatic hernia. Am J Physiol Lung Cell Mol Physiol 278: L923-L932, 2000.

62. Thébaud B, Ladha F, Michelakis ED, Sawicka M, Thurston G, Eaton F, Hashimoto K, Harry G, Haromy A, Korbutt G, Archer SL. Vascular endothelial growth factor gene therapy increases survival, promotes lung angiogenesis, and prevents alveolar damage in hyperoxiainduced lung injury: evidence that angiogenesis participates in alveolarization. Circulation 112: 2477-2486, 2005.

63. Tibboel D, Shehata SM, Guldemeester AH. The pulmonary vasculature in congenital diaphragmatic hernia. Fetal and neonatal pulmonary. Circulation 355-378, 2000 